\title{
INFLUENCE OF INDUCTION AGENT ON PULMONARY VENOUS ADMIXTURE DURING HALOTHANE:OXYGEN ANAESTHESIA WITH CONTROLLED RESPIRATION IN MAN
}

\author{
Bryan E. Marshall, M.D., 'Doreen A. Hoffman, M.D., $\uparrow$ \\ Gordon R. Neuferd, M.D., $\{$ and Ethan T. Colton, M.D. $\$$
}

General ANAeSthesia ${ }^{1-3}$ may be associated with an inefficient gas exchange causing an increased alveolar-arterial oxygen tension difference $\left(\mathrm{AaDo}_{2}\right)$. Current evidence favors primarily mechanical causes ${ }^{4,5}$, but the possibility of different pharmacological effects from anaesthetic agents has not been evaluated. The purpose of the present studies was to determine whether an inefficient oxygen exchange was an inevitable accompaniment of general anaesthesia, and also to compare the effects of two induction agents on the subsequent course of anaesthesia.

\section{OUTLINE OF STUdY}

These investigations were performed in six healthy adult male volunteers after a physical examination and medical history had been performed (mean age $23.3 \pm$ S.E. 0.8 years). A full explanation of the procedures was given, and written consent obtained.

The studies were begun after an 8 to 10 hour fast. Electrocardiographic plates were attached to the limbs. A 36-in. catheter (Bardic "Intracath" $16 \mathrm{Ga}$ ), connected to a pressure transducer, was inserted percutaneously into a vein and advanced until a pulmonary artery tracing was obtained. A femoral artery was cannulated (Argyle $18 \mathrm{Ga}$ ) percutaneously. Electrocardiogram and systemic and pulmonary artery pressures were recorded on a polygraph. A rectal thermistor probe was inserted.

The subjects began breathing 100 per cent oxygen in a non-return system consisting of an oxygen reservoir bag and a Frumin valve. At the end of 20 to 30 minutes, blood and gas samples were obtained for the calculation of $\mathrm{AaDo}_{2}$, arterio-venous oxygen content difference $\left(\mathrm{CaO}_{2}-\mathrm{C} \overline{\mathrm{v}} \mathrm{O}_{2}\right)$, cardiac index $(\mathrm{CI})$, and per cent pulmonary venous admixture $\left(\dot{Q}_{s} / \dot{Q}_{c} \%\right)($ Phase 1$)$.

From The Department of Anaesthesia, University of Pennsylvania, School of Medicine, Philadelphia, Pennsylvania.

${ }^{\circ}$ Dr. Marshall is a Professor.

†Dr. Hoffman's present address is Department of Anaesthesia, Letterman General Hospital, San Francisco, California.

tDr. Neufeld is an Assistant Professor.

$\$ D r$. Colton's present address is Department of Anaesthesia, University of Connecticut Medical Center, Hartford, Connecticut.

This work was supported (in part) by U.S.P.H.S. Grants 5-PO1-GM-15430-02 and 5-PO1GM-09070-06 from the National Institute of General Medical Sciences, National Institutes of Health. Dr. Marshall is the recipient of a Research Career Development Award, 1-K4-HL-49,965-02, and Dr. Neufeld a Special Fellowship Award, from the National Heart and Lung Institute, National Institutes of Health. 
General anaesthesia was then induced either with intravenous thiopentone (3 $\mathrm{mg} / \mathrm{kg}$ ) (Phase 2) or with halothane:oxygen alone (Phase 3). Tracheal intubation was facilitated and muscular relaxation ensured by an infusion of succinylcholine chloride ( 0.1 per cent in 5 per cent dextrose, approximate total dose $300 \mathrm{mg}$ ). The lungs were mechanically hyperventilated (Emerson ventilator) with large tidal volumes $(8-10 \mathrm{ml} / \mathrm{kg}$ ) of oxygen and halothane (mean alveolar halothane, $\mathrm{P}_{\mathrm{A}}$ Halo $=6.1$ torr) to which carbon dioxide was added to maintain a constant end-tidal carbon dioxide tension $\left(\mathrm{P}_{\mathrm{ET}} \mathrm{CO}_{2}\right.$ ) (Godart Capnograph $\mathrm{CO}_{2}$ analyzer).

One hour after inducing anaesthesia, all the measurements described for Phase 1 were repeated and are identified as Phase 2 if the induction was with thiopentone and Phase 3 if with halothane:oxygen alone.

Halothane was then discontinued until EEG, blood pressure, and pulse rate evidence of "awakening" were observed. At this time, anaesthesia was reinduced with whichever technique had not been used on the first occasion. After maintaining halothane:oxygen anaesthesia with a constant $\mathrm{P}_{\mathrm{ET}} \mathrm{CO}_{2}$ as before for a further one hour, the measurements were repeated.

In each volunteer, three sets of measurements were, therefore, made. Phase 1 measurements were always obtained first, but the order of Phase 2 and 3 measurements were randomly determined. In three subjects the order of measurements was $1,2,3$ and in the other three subjects $1,3,2$.

\section{Analytic Methods}

The arterial blood gas tensions ( $\mathrm{PaO}_{2}$ and $\left.\mathrm{PaCO}_{2}\right)$ were measured with a microelectrode system (Corning) calibrated with gases of known composition and corrected for temperature effects. To ensure accuracy with the measurement of $\mathrm{PaO}_{2}$ during 100 per cent oxygen breathing, special care was taken in sampling. Heparinized ground glass syringes were employed, and the heparin of the dead space was flushed with blood to avoid the dilution effect of the heparin. The electrodes were calibrated with the sample drawn and introduced immediately into the cuvette with no time delay or cooling before measurement. An individual gas:blood ratio was obtained by tonometry and averaged 1.04 .

Inspired $\left(P_{1}\right)$ and mixed expired $\left(P_{F}\right)$ gases were continuously sampled and analyzed with a paramagnetic oxygen analyzer (Beckman E-2) and an infrared carbon dioxide analyzer (Godart Capnograph).

Oxygen content of arterial $\left(\mathrm{CaO}_{2}\right)$ and mixed venous $\left(\mathrm{C}_{\overline{2}} \mathrm{O}_{2}\right)$ blood were analyzed with a polarographic electrode technique ${ }^{6}$ based on the displacement of oxygen from haemoglobin by carbon monoxide.

Cardiac output was measured by dye dilution (Gilson DTL dye tracer) using an injection ( $10 \mathrm{mg}$ ) of indocyanine green into the pulmonary artery.

Minute ventilation and tidal volume were measured with a dry gas meter and corrected to BTPS conditions.

Mixed expired ( $\left.\mathrm{P}_{\mathrm{E}} \mathrm{Halo}\right)$ and inspired $\left(\mathrm{P}_{\mathrm{l}} \mathrm{Halo}\right)$ halothane concentrations were analyzed by gas chromatography (F \& M Model 400). 


\section{Calculations}

Inspired oxygen concentration was at all times near 100 per cent, so the following alveolar gas equation was used.

$$
\mathrm{P}_{\mathrm{A}} \mathrm{O}_{2}=\mathrm{P}_{\mathrm{I}} \mathrm{O}_{2}-\mathrm{P}_{\mathrm{W}}-\mathrm{P}_{\mathrm{A}} \mathrm{CO}_{2}
$$

Where $\mathrm{P}_{\mathrm{W}}=$ saturated water vapor tension at body temperature, $\mathrm{P}_{\mathrm{A}} \mathrm{CO}_{2}=$ $\mathrm{PaCO}_{2}$.

Inspired and mixed expired halothane concentrations were close enough so that no significant error was introduced by assuming $\mathrm{P}_{\mathrm{I}} \mathrm{Halo}=\mathrm{P}_{\mathrm{A}} \mathrm{Halo}$.

Pulmonary shunt was calculated from:

$$
\grave{Q}_{\mathrm{B}} / \phi_{\mathrm{c}} \%=\frac{\mathrm{AaDo}_{2} \times 0.0031}{\left[\mathrm{AaDo}_{2} \times 0.0031\right]+\left(\mathrm{CaO}_{2}-\mathrm{C} \overline{\mathrm{v}} \mathrm{O}_{2}\right)} \times 100
$$

where 0.0031 is the solubility coefficient of oxygen in plasma. Significance of differences was tested with analysis of variance.

\section{REsults}

The mean data at each of the three phases are shown in Table I. Temperature and $\mathrm{PaCO}_{2}$ did not vary throughout.

During anaesthesia, the $P_{A}$ Halo was $6.3 \pm$ S.E. 0.6 and $6.0 \pm$ S.E. 1.4 torr in Phases 2 and 3 respectively. Minute ventilation $\left(\dot{V}_{E}\right)$ was increased from $7.09 \pm$ S.E. $0.56 \mathrm{~L} / \mathrm{min}$ awake to $7.83 \pm$ S.E. 0.68 (Phase 2) and $8.0 \pm$ S.E. 0.69 (Phase 3) $\mathrm{L} / \mathrm{min}$.

Cardiac index was $2.91 \pm$ S.E. $0.12 \mathrm{~L} / \mathrm{min}$ in Phase 1 and was reduced 14 per cent to $2.33 \pm$ S.E. 0.19 (Phase 2) and $2.22 \pm$ S.E. 0.20 (Phase 3). Similarly, Vัo was $229 \pm$ S.E. $18 \mathrm{ml} / \mathrm{min}$ awake and reduced 14.5 per cent to $190 \pm$ S.E. 18 (Phase 2) and $189 \pm$ S.E. 23 (Phase 3). It follows that $\mathrm{CaO}_{2}-\mathrm{C}_{\bar{v}} \mathrm{O}_{2}$ was unchanged throughout.

Systemic arterial pressure (S.A.P.) decreased from $88 \pm$ S.E. 3 torr before anaesthesia to $61 \pm$ S.E. 4 (Phase 1) and $65 \pm$ S.E. 3 (Phase 2). Conversely, pulmonary artery pressure increased from $11.2 \pm$ S.E. 1.2 torr (Phase 1) to $16.1 \pm$ S.E. 1.8 (Phase 2) and $14.8 \pm$ S.E. 1.2 (Phase 3). Awake $\mathrm{AaDo}_{2}$ was $38 \pm$ S.E. 13 torr and $\dot{Q}_{\mathrm{s}} / \dot{Q}_{\mathrm{c}} 2.94 \pm$ S.E. 0.51 per cent and these were significantly increased during anaesthesia only during Phase 3 . In addition, there were consistent differences between Phases 2 and 3. Thus, $\mathrm{AaDo}_{2}$ increased $8.0 \pm$ S.E. 2.1 torr and $\dot{\mathrm{Q}}_{\mathrm{s}} / \dot{\mathrm{Q}}_{\mathrm{c}}$ increased by $0.82 \pm$ S.E. 0.26 per cent on changing from Phase 2 to Phase 3 . Both these changes were significant $(\mathrm{P}<0.02)$.

\section{Discussion}

Hypoxaemia during anaesthesia has been the subject of many investigations in the past decade. A recent review ${ }^{7}$ concluded that this inefficient exchange of oxygen was most probably attributable to changes in lung mechanics that follow 
TABLE I

Means \pm Standard Error of Measurements from Six Men

\begin{tabular}{|c|c|c|c|}
\hline & \multirow{2}{*}{$\begin{array}{c}\text { Awake } \\
\text { Control } \\
1 \\
\end{array}$} & \multicolumn{2}{|c|}{ Anaesthesia Induction } \\
\hline & & $\begin{array}{c}\text { Thiopentone } \\
2\end{array}$ & $\begin{array}{c}\text { Halothane } \\
3\end{array}$ \\
\hline Temperature & $36.9 \pm 0.1$ & $36.5 \pm 0.1$ & $36.6 \pm 0.1$ \\
\hline$\underset{\text { torr }}{\mathrm{PaCO}_{2}}$ & $38.4 \pm 0.9$ & $40.8 \pm 1.4$ & $41.7 \pm 1.8$ \\
\hline $\mathrm{P}_{\mathrm{A}}$ Halo & - & $6.3 \pm 0.6$ & $6.0 \pm 1.4$ \\
\hline$\underset{\mathrm{L}}{\mathrm{V}_{\mathrm{E}} \text { (BTPS) }}$ & $7.09 \pm 0.56$ & $7.83 \pm 0.68^{*}$ & $8.00 \pm 0.69^{*}$ \\
\hline $\begin{array}{l}\text { breaths/min } \\
\text { S.A. A.P. }\end{array}$ & $13.7 \pm 1.2$ & $11.6 \pm 0.6$ & $11.7 \pm 0.6$ \\
\hline $\begin{array}{l}\text { torr } \\
P . \bar{A} . P .\end{array}$ & $88 \pm 3$ & $61 \pm 4^{*}$ & $65 \pm 3^{*}$ \\
\hline $\mathrm{CI}^{\text {torr }}$ & $11.2 \pm 1.2$ & $16.1 \pm 1.8^{*}$ & $14.8 \pm 1.2^{*}$ \\
\hline $\begin{array}{r}\mathrm{L} / \mathrm{min} / \mathrm{m}^{2} \\
\mathrm{VO}_{2}(\mathrm{STPD})\end{array}$ & $2.91 \pm 0.12$ & $2.33 \pm 0.19^{*}$ & $2.22 \pm 0.20^{\circ}$ \\
\hline $\begin{array}{c}\mathrm{ml} / \mathrm{min} \\
\mathrm{CaO}_{2}-\mathrm{CvO}_{2}\end{array}$ & $229 \pm 18$ & $190 \pm 18$ & $189 . \pm 23$ \\
\hline $\begin{array}{c}\mathrm{ml} / 100 \mathrm{ml} \\
\mathrm{PaO}_{2}\end{array}$ & $3.94 \pm 0.11$ & $3.86 \pm 0.20$ & $3.88 \pm 0.31$ \\
\hline torr & $629 \pm 14$ & $625 \pm 15$ & $617 \pm 15 \dagger^{*}$ \\
\hline $\begin{array}{l}\mathrm{AaDO}_{2} \\
\text { torr }\end{array}$ & $38 \pm 13$ & $38 \pm 13$ & $46 \pm 12 \dagger^{*}$ \\
\hline $\begin{array}{c}Q_{\mathrm{g}} / \mathrm{Q}_{\mathrm{c}} \\
\%\end{array}$ & $2.94 \pm 0.51$ & $2.99 \pm 1.05$ & $3.81 \pm 1.2 \dagger^{\circ}$ \\
\hline
\end{tabular}

*Dilference from control value significant $(P<0.05)$ from analysis of variance.

†Differcnce between Phase 2 and 3 significant $(P<0.05)$ from analysis of variance.

a reduction of functional residual capacity (FRC). Airway closure, microatelectasis, and abnormal ventilation/perfusion distributions are specific sequelae that may become manifest when FRC is reduced and also account for an increased alveolar to arterial oxygen tension difference.

Positive end-expiratory pressure during general anaesthesia restores FRC and AaDo.2 toward normal. ${ }^{8}$ Anaesthesia with spontaneous respiration results in a reduced FRC, and a previous study from this laboratory demonstrated a three to fourfold increase in $\hat{Q}_{\mathrm{s}} / \dot{Q}_{\mathrm{C}} \%$ associated with respirations that were more rapid and shallow than in the awake state. ${ }^{3}$ In the present study during anaesthesia the lungs were ventilated mechanically at a slow rate and with a large tidal volume. This pattern of ventilation is associated with an improved ventilation of lung units and maintenance of a near-normal functional residual capacity. In sharp contrast to our previous findings with spontaneous respiration, the present study disclosed only small changes of $\mathrm{AaDo}_{2}$ and $\dot{\mathrm{Q}}_{\mathrm{s}} / \dot{\mathrm{Q}}_{\mathrm{c}} \%$. This work, therefore, supports the hypothesis that large tidal volume ventilation is effective in preventing inefficient oxygenation during anaesthesia. 
However, while the changes of $\mathrm{AaDo}_{2}$ and $\dot{\mathrm{Q}}_{\mathrm{B}} / \dot{\mathrm{Q}}_{\mathrm{c}} \%$ observed during anaesthesia were small, there was a statistically significant difference between the results obtained during Phases 2 and 3 of the study. In all subjects both $\mathrm{AaDo}_{2}$ and $\dot{\mathrm{Q}}_{\mathrm{B}} / \dot{\mathrm{Q}}_{\mathrm{C}} \%$ increased following halothane:oxygen induction (Phase 3) as compared to a thiopentone induction and it should be re-emphasized that the order of these two phases was randomized.

These studies were not designed to elucidate mechanisms but there are several possibilities including pharmacological actions of thiopentone on bronchi or pulmonary vessels or events concomitant with induction by an anaesthetic gas mixture versus an intravenous agent. The recent demonstration that inhalation agents abolish the hypoxic pulmonary vasoconstrictor response ${ }^{9}$ suggests that this effect can cause arterial hypoxaemia and might explain the present observations.

The differences observed would have been undetectable with a less rigorous study design ${ }^{10}$ and appear to be the first to show that the choice of anaesthetic agent influences intrapulmonary oxygen exchange. While the clinical significance of these changes is negligible here, it is possible that such effects become exacerbated in patients with cardiopulmonary disease. Further observations in such patients are warranted.

\section{SUMMary}

In six healthy unpremedicated, adult male volunteers (mean age 23 years), cardiac index (CI) (mean = 2.91 \pm S.E. $0.12 \mathrm{~L} / \mathrm{min} / \mathrm{kg}$ ), alveolar-arterial oxygen tension difference $\left(\mathrm{AaDo}_{2}\right)$ (mean $=38 \pm \mathrm{S} . \mathrm{E} .13$ torr $)$, and percent pulmonary venous admixture $\left(\dot{\mathrm{Q}}_{\mathrm{s}} / \dot{\mathrm{Q}}_{\mathrm{c}} \%\right)($ mean $=2.94 \pm$ S.E. $0.51 \%)$ were measured breathing 100 per cent oxygen (Phase 1). Anaesthesia was then induced either with thiopentone $(3 \mathrm{mg} / \mathrm{kg}$ ) (Phase 2 ) or halothane:oxygen (Phase 3 ) and maintained in both cases with oxygen:halothane for one hour with mechanical ventilation. Halothane was then discontinued until awakening and anaesthesia reinduced with the agent not previously used, and measurements of Phases 2 and 3 repeated after another one hour. Temperature, $\mathrm{PaCo}_{2}$, ventilation, cardiac output, and blood pressure were unchanged. The efficiency of oxygen exchange in the lungs following a thiopentone induction was significantly better than that following a halothane: oxygen induction. After thiopentone induction $\mathrm{AaDo}_{2}$ (mean $=38 \pm$ S.E. 13 torr) and $\dot{\mathrm{Q}}_{\mathrm{s}} / \dot{\mathrm{Q}}_{\mathrm{c}}$ (mean $=2.99 \pm$ S.E. 1.05\%) were unchanged from the awake values, while following halothane:oxygen induction $\mathrm{AaDo}_{2}$ (mean $=48 \pm$ S.E. 12 torr) and $\dot{\mathrm{Q}}_{\mathrm{B}} / \dot{\mathrm{Q}}_{\mathrm{c}}($ mean $=3.81 \pm 1.2$ torr $)$ were significantly $(\mathrm{P}<0.05)$ increased.

\section{RÉSUMÉ}

Cette étude fut effectuée chez six jeunes volontaires de sexe masculin, en bonne santé. Dans un premier temps, (Phase 1) on leur fit respirer de l'oxygène à 100 pour cent, puis l'on procéda à la mesure de leur index cardiaque (moyenne = $2.91 \pm 0.12 \mathrm{~L} / \mathrm{Kilo} / \mathrm{min}$ ), de leur gradient Alvéolo-artériel “AaDo " (moyenne $38 \pm 13$ torr) et du shunt physiologique $\dot{\mathrm{Q}}_{\mathrm{s}} / \dot{\mathrm{Q}}_{\mathrm{c}} \%$ (moyenne $2.94 \pm 0.51 \%$ ).

Puis les sujets furent anesthésiés et l'induction fut réalisée soit avec du Thiopentane (Phase 2) ou avec un mélange d'Halothane-Oxygène (Phase 3). Dans les 
deux cas, l'anesthésie fut maintenue une heure à l'Halothane-Oxygène et les sujets ventilés mécaniquement. Au bout de cette heure, les mesures de la Phase 1 furent répétées et les résultats classifiés comme appartenant à la Phase 2 ou à la Phase 3, selon l'agent d'induction utilisé.

L'Halothane fut alors cessé jusqu'à ce que les sujets manifestent des signes d'éveil (E.C.G., P.A. et fréquence cardiaque). A ce moment l'anaesthésie fut réinduite avec la méthode (Phase 2 ou 3), non utilisée la première fois, et à nouveau, au bout d'une heure de maintien à l'Halothane-Oxygène, les mesures de la Phase 1 furent répétées.

La température, la $\mathrm{PaCo}_{2}$, la ventilation, la débit cardiaque et la tension artérielle demeurèrent inchangés.

L'efficacité du transfer d'oxygène au niveau des poumons fut meilleure après l'induction au Thiopentone qu'après l'induction à l'Halothane-Oxygène. L'induction au Thiopentone n'apporta aucun changement du gradient alvéolo-artériel ni du shunt, alors que ces deux paramètres furent augmentés de façon significative à la suite de l'induction Halothane-Oxygène.

\section{REFERENCES}

1. Bendixen, H.H., Hedley-Whyte, J., \& LAVER, M.B. Impaired oxygenation in surgical patients during general anesthesia with controlled ventilation: a concept of atelectasis. New Engl. J. Med. 269: 991-996 (1963).

2. NunN, J.F. Factors influencing the arterial oxygen tension during halothane anaesthesia with spontaneous respiration. Br. J. Anaesth. 36:327-341 (1964).

3. Marshall, B.E., Cohen, P.J., Klincenmaier, C.H., \& Aukhurg, S. Pulmonary venous admixture before, during and after halothane:oxygen anaesthesia in man. J. Appl. Physiol. 27: 653-657 (1969).

4. Couture, J., Picken, J., Trop, D., Ruff, F., Lousada, N., Houseley, E., \& Bates, D.V. Airway closure in normal, obese and anaesthetized supine subjects. Fed. Proc. 29: 269 (1970).

5. Don, H.F., Craig, D.D., Warba, W.M., \& Couture, J.G. The measurement of gas trapped in the lungs at functional residual capacity and the effects of posture. Anesthesiology 35 : 582-590 (1971).

6. Klingenmaier, C.H., Behar, M.G., \& SMith, T.C. Blood oxygen content measured by oxygen tension increase after release of hemoglobin by carbon monoxide. J. Appl. Physiol. 26: 653-655 (1969).

7. Marshall, B.E. \& WyChe, M.Q. Hypoxemia during and after anesthesia. Anesthesiology 37: 178-209 (1972).

8. Wyche, M.Q., Teichner, R.L., Kallos, T., Marshall, B.E., \& SMITh, T.C. Effects of continuous positive-pressure breathing on functional residual capacity and arterial oxygenation during intra-abdominal operation. Anesthesiology 38: 68-74 (1973).

9 Sykes, M.K., Davies, D.M., Chakrabarti, M.K., \& Loh, L. The effects of halothane, trichloroethylene, and ether on the hypoxic pressor response and pulmonary vascular resistance in the isolated, perfused cat lung. Brit. J. Anaesth. 45: 655-663 (1973).

10. Stone, J.G. \& Sullivan, S.F. Halothane and pulmonary shunting. Anesthesiology 37 : 582-587 (1972). 